\title{
MEREFLEKSIKAN KEADILAN BAGI KONSUMEN TERKAIT KEPATUTAN PROMOSI TRANSAKSI NON-TUNAI
}

\author{
Winda Wijayanti \\ Peneliti Mahkamah Konstitusi Republik Indonesia \\ Jl. Medan Merdeka Barat No. 6 Jakarta Pusat 10110 \\ E-mail : stillbest_leo@yahoo.com
}

\begin{abstract}
Although Law Number 8 of 1999 on Consumer Protection has been enforced for 20 years, there are regulations to protect consumer, and submissions to the Constitutional Court 3 times, the material of Consumer Protection Law has never been canceled and changed. This normative juridical study aims to analyze whether or not the Consumer Protection Lawneeds to be amended to fulfill the legal necessities of the community. Merchant (bank) with the Central Bank of Indonesia policy compete to provide the best promotions so that customers are interested. The selection pay with electronic money causes the powerlessness of consumers to prefer buying goods/services cheaper with cards rather than cash without any promotion of the price of goods/ services or pay normal prices as inappropriate to consumers that pay non-cash. Discrimination or different treatment of the price of goods or services that harm consumers who transact in cash result unfairness does not protect the dignity of consumers.
\end{abstract}

Key words: fairness, consumer, properness of promotion, non-cash transaction

\begin{abstract}
Abstrak
Meskipun terdapat Undang-Undang No.8 Tahun 1999 tentang Perlindungan Konsumen (UUPK) yang telah berlaku selama 20 tahun, beberapa Peraturan Pemerintah untuk perlindungan hukum bagi konsumen, dan pengajuan ke Mahkamah Konstitusi sebanyak 3 kali, namun materi UUPK belum pernah dibatalkan atau mengalami perubahan. Penelitian yuridis normatif ini bertujuan menganalisa perlu tidaknya merubah UUPK untuk memenuhi kebutuhan hukum masyarakat. Bank dengan dukungan kebijakan BI bersaing untuk memberikan promosi terbaik agar nasabah tertarik. Pilihan cara pembayaran dengan uang elektronik menyebabkan ketidakberdayaan konsumen untuk memilih membeli barang/jasa lebih murah dengan memakai kartu daripada membayar tunai tanpa promosi harga barang/jasa atau membayar harga normal sebagai ketidakpatutan promosi bagi konsumen transaksi non tunai. Diskriminasi/perbedaan perlakuan atas harga barang/layanan jasa yang merugikan konsumen yang bertransaksi secara tunai menyebabkan ketidakadilan konsumen membayar secara tunai dan tidak melindungi harkat dan martabat konsumen.
\end{abstract}

Kata kunci: keadilan, konsumen, kepatutan promosi, transaksi non-tunai 


\section{Latar Belakang}

Bank Indonesia (BI) telah mencanangkan Gerakan Nasional Non-Tunai (GNNT) pada tanggal 14 Agustus 2014 yang bertujuan mendorong masyarakat untuk mulai menggunakan alat transaksi non tunai dalam aktivitas sehari-hari untuk kemudahan, keamanan yang mencegah kriminalitas saat transaksi dengan membawa uang tunai, dan mendukung perekonomian melalui peningkatan percepatan peredaran uang (velocityofmoney). ${ }^{1} \mathrm{GNNT}$ sebagaipenyegaran kembali Peraturan Pemerintah Nomor 82 Tahun 2012 tentang Penyelenggaraan Sistem dan Transaksi Elektronik dalam Layanan Keuangan Digital, yang diharapkan dapat mengakselerasi penggunaan instrumen pembayaran non-tunai yang telah diupayakan oleh BI dari beberapa tahun sebelumnya, diantaranya sektor transportasi publik meliputi TransJogja, TransSolo, dan TransJakarta. ${ }^{2}$

GNNT merupakan suatu gerakan secara nasional agar alat pembayaran atas transaksi barang dan/jasa masyarakat Indonesia beralih dari tunai menjadi transaksi non-tunai berdasarkan Peraturan Bank Indonesia
Nomor 19/8/PBI/2017 tentang Gerbang Pembayaran Nasional (National Payment Gateway) tanggal 22 Juni 2017 (PBI Nomor 19/8/PBI/2017). Salah satu latar belakang GNNT bagi pemerintah Indonesia adalah penghematan uang negara untuk biaya cetak dan distribusi uang fisik diperkirakan sebesar 16 triliun per tahun. ${ }^{3}$ Transaksi non-tunai diantaranya terdiri atas e-money, kartu debet, dan kartu kredit. ${ }^{4}$ Transaksi non-tunai yang demikian menurut BI adalah efisien dan bermanfaat, namun konsumen yang masih tradisional memakai transaksi secara tunai belum mendapatkan perlindungan hukum yang memadai bagi untuk diperlakukan adil oleh penjual saat melakukan pembayaran, misalnya kasus di tempat perbelanjaan hanya menyediakan promosi berupa potongan harga (diskon) untuk pemegang kartu tertentu dan untuk konsumen transaksi tunai dikenai harga normal, pembayaran parkir hanya dapat melalui kartu OVO di tempat parkir pusat perbelanjaan (mall), ${ }^{5}$ dan lain-lain. Beberapa contoh kasus tersebut menyebabkan perlakuan yang berbeda antar Konsumen oleh penjual atas promosi barang dan/jasa yang

1 Bank Indonesia, "Bank Indonesia dan Kompasiana: Jelajah Non Tunai”, https://www.bi.go.id/id/ruang-media/ info-terbaru/Pages/Bank-Indonesia-dan-Kompasiana-Jelajah-Non-Tunai.aspx, diakses 26 Agustus 2019.

2 Sutarmin, dkk., "Potensi Pengembangan Transaksi Non Tunai Di Indonesia”, Sustainable Competitive Advantage Journal Vol. 7, No. 1, (2017): 293.

3 Indira Rezkisari, "Gerakan Non-Tunai hemat Rp 16 T Biaya Cetak Uang", https://www.republika.co.id/berita/ dunia-islam/fatwa/14/07/21/ekonomi/keuangan/17/10/18/oy0 k63328-gerakan-nontunai-hemat-rp-16-t-biayacetak-uang, diakses 26 Agustus 2019.

4 Muhammad Lukmanulhakim, dkk., "Pengaruh Transaksi Non-Tunai Terhadap Velositas Uang Di Indonesia", Jurnal Ekonomi Pembangunan Vol. 14, No. 1, (Juni 2016): 41-42.

5 Athika Rahma, "Kasus Monopoli OVO Masuk Penyelidikan KPPU", https://www.liputan6. $\mathrm{com} / \mathrm{bisnis} / \mathrm{read} / 4047520 / \mathrm{kasus}$-monopoli-ovo-masuk-penyelidikan-kppu?utm_expid=.9Z4i5 ypGQeGiS7w9arwTvQ.0\&utm_referrer=https\%3A\%2F\%2Fwww.google.com\%2F, diakses 27 Agustus 2019. 
menyebabkan harga barang dan/jasa menjadi berbeda, karena cara pembayarannya secara tunai atau tidak menggunakan kartu tertentu.

Globalisasi dan perdagangan bebas yang didukung oleh kemajuan teknologi telekomunikasi yang memperluas ruang gerak arus transaksi barang dan/atau jasa dan berakibat barang dan/atau jasa yang ditawarkan bervariasi. Konsumen dapat memperoleh manfaat atas kebutuhan akan barang dan/ atau jasa yang diinginkan dapat terpenuhi dan semakin bervariasi, karena adanya kebebasan memilih aneka jenis dan kualitas barang dan/atau jasa sesuai dengan keinginan dan kemampuan konsumen. ${ }^{6}$ Kemudahan transaksi yang bersifat global diikuti dengan kemajuan informasi telekomunikasi sangat pesat dapat berakibat kerugian bagi konsumen pada saat perlindungan konsumen itu tidak ada. Pada prinsipnya, kebutuhan paling mendasar bagi setiap orang adalah perlindungan terhadap hak-haknya sebagai manusia. ${ }^{7}$ Keadaan itu menyebabkan kedudukan pelaku usaha dan konsumen menjadi tidak seimbang, maka konsumen berada dalam posisi lemah. ${ }^{8}$

Konsumen memperoleh perlindungan hukum sejak berlaku Undang-Undang Nomor 8 Tahun 1999 tentang Perlindungan Konsumen (UU Nomor 8 Tahun 1999) berhak untuk memilih barang dan/jasa dan cara pembayaran tanpa diperlakukan secara diskriminatif sesuai Pasal 4 ayat (7) UU Nomor 8 Tahun 1999 yang berbunyi "Hak konsumen adalah:

7. hak untuk diperlakukan atau dilayani secara benar dan jujur serta tidak diskriminatif;",

Setiap konsumen selayaknya mendapatkan perlakuan yang sama oleh pelaku usaha untuk terefleksinya keadilan adalah hak asasi setiap konsumen sebagaimana diatur dalam Pasal 28D ayat (1) Undang-Undang Dasar Negara Republik Indonesia Tahun 1945 (UUD 1945) yang berbunyi "Setiap orang berhak atas pengakuan, jaminan, perlindungan, dan kepastian hukum yang adil serta perlakuan yang sama di hadapan hukum." agar mereka mendapatkan harkat dan martabat yang setara dalam setiap transaksi. Perlindungan akan harkat dan martabat, serta pengakuan atas hak-hak asasi manusia yang dimiliki oleh subyek hukum berdasarkan hukum sebagai perlindungan hukum. ${ }^{9}$

Terkait kepentingan konsumen, Persatuan Bangsa-bangsa (PBB) sebelumnya telah memberikan perhatian dalam Sidang Umum ke-106 tanggal 9 April 1985 meliputi perlindungan konsumen dari bahaya terhadap kesehatan dan keamanannya, promosi dan

6 Ahmadi Miru dan Sutarman Yodo, Hukum Perlindungan Konsumen, (Jakarta: PT. RajaGrafindo Persada, 2004), hlm. 37.

7 Achmad Edi Subiyanto, "Perlindungan Hak Konstitusional Melalui Pengaduan Konstitusional," Jurnal Konstitusi Vol. 8, No. 5, (Oktober 2011): 708.

8 Fabian Fadhly, "Ganti Rugi Sebagai Perlindungan Hukum Bagi Konsumen Akibat Produk Cacat," Arena Hukum Vol. 6, No. 2, (Agustus 2013): 237.

9 Desry Ary Setyawati, dkk., "Perlindungan Bagi Hak Konsumen dan Tanggung Jawab Pelaku Usaha Dalam Perjanjian Transaksi Elektronik," Syiah Kuala Law Journal Vol. 1, No. 3, (Desember 2017): 36. 
perlindungan pada kepentingan ekonomi konsumen, tersedianya cukup informasi yang memungkinkan pilihan sesuai kehendak, pendidikan konsumen, cara-cara ganti rugi yang efektif, dan kebebasan membentuk organisasi konsumen melalui kesempatan untuk menyatakan pendapat untuk pengambilan keputusan. ${ }^{10}$ Untuk Indonesia, perlindungan konsumen diatur dalam UU Nomor 8 Tahun 1999 yang telah berlaku selama 21 tahun, namun sampai saat ini belum pernah diubah sama sekali bahkan setelah diajukan ke MK sebanyak 3 (tiga) perkara tidak pernah dinyatakan materi muatan ayat, pasal, dan atau/bagian UU tersebut bertentangan dengan UUD 1945 dan tidak berlaku secara mengikat. ${ }^{11}$ Penulisan ini mencakup permasalahan keadilan bagi konsumen yang bertransaksi tunai dan kepatutan promosi atas transaksi non-tunai di masa mendatang terkait Gerakan Nasional Non-Tunai (GNNT) oleh BI. Pada pelaksanaannya terjadi: (1) diskriminasi konsumen atas promosi barang dan/jasa karena perbedaan cara pembayaran oleh konsumen (tunai dan non-tunai) yang berakibat perbedaan harga barang dan/jasa yang harus dibayarkan oleh konsumen bahwa transaksi non-tunai mendapatkan promosi (potongan harga atau manfaat lainnya), sedangkan transaksi tunai membayar dengan harga normal atau tidak mendapatkan promosi apa pun; dan (2) transaksi non-tunai dapat mengikis budaya baik masyarakat Indonesia diantaranya menghargai uang dengan berhemat atau menabung dan menyumbang fakir miskin. Penulisan ini adalah penelitian yuridis normatif terhadap asas-asas hukum untuk menemukan asas hukum atau doktrin hukum positif yang berlaku (study dogmatic atau penelitian doktrinal (doctrinal research) melalui metode historis untuk menjelaskan masa lampau, kejadian sekarang yang sedang berlangsung/berlaku, dan di masa mendatang. ${ }^{12}$ Analisa UU Nomor 8 Tahun 1999 dan UU BI terkait manfaat GNNT bagi masyarakat dan pemerintah dan kesiapan masyarakat atas GNNT adalah sangat penting untuk merefleksikan keadilan melalui perubahan UU Nomor 8 Tahun 1999.

Sebagaimana disampaikan oleh Andre Ata Ujan, sikap kritis terhadap hukum sangat penting untuk mendorong hukum ke arah

10 Az. Nasution, "Sekilas Hukum Perlindungan Konsumen," Majalah Hukum dan Pembangunan, Tahun XVI No. 6, Jakarta: FH UI, 1986, hlm. 70. Dalam Holijah, "Pengintegrasian Urgensi dan Eksistensi Tanggung Jawab Mutlak Produk Barang Cacat Tersembunyi Pelaku Usaha Dalam Undang-Undang Perlindungan Konsumen di Era Globalisasi," Jurnal Dinamika Hukum Vol. 14, No. 1, (Januari 2014): 178.

11 Perkara Mahkamah Konstitusi Nomor 74/PUU-IX/2011 perihal Pengujian Pasal 8 ayat (1) huruf j dan Pasal 62 ayat (1) UU Nomor 8 Tahun 1999 tentang Perlindungan Konsumen, Perkara Nomor 65/PUU-XIII/2015 perihal Pengujian Pasal 4 huruf c dan Pasal 7 huruf b UU Nomor 8 Tahun 1999 (pencantuman informasi nama dan domisili lengkap dari badan hukum/pelaku usaha yang bertanggung jawab atas barang dan/atau jasa yang diproduksi atau dijual), dan Perkara Mahkamah Konstitusi Nomor 91/PUU-XV/2017 perihal Pengujian Pasal 4 huruf b UU Nomor 8 Tahun 1999 (hak konsumen untuk memilih pembayaran atas penggunaan jalan). Ketiga perkara itu diperiksa, diputus, dan diadili dengan amar bahwa permohonan Pemohon tidak dapat diterima.

12 H. Zainuddin Ali, Metode Penelitian Hukum, (Jakarta: Sinar Grafika, 2014), hlm. 24-25. 
kemanusiaan agar manusia tidak diperbudak oleh hukum. Refleksi kritis atas hukum penting, karena masyarakat berkepentingan terhadap penegakan kepentingan umum berupa tertib sosial untuk pelaksanaan hak dan perwujudan kepentingan warga negara dan untuk mengontrol kesewenangwenangan penguasa. ${ }^{13}$ Menurut Gustav Radburch terdapat 3 (tiga) unsur yang harus selalu diperhatikan dalam hukum, yaitu kepastian hukum (rechtssicherheit), kemanfaatan (zweckmassigkeit), dan keadilan (gerechtigkeit), ${ }^{14}$ namun pada hakikatnya hukum dan keadilan tidak dapat berjalan bersamaan. ${ }^{15}$ Hal itu tentu akan menimbulkan permasalahan bagi konsumen sebagai pihak yang lemah dalam perjanjian jual beli barang dan/jasa, apabila ketiga unsur dalam penegakan hukum tidak terlaksana. Berdasarkan pemikiran itu, maka refleksi hukum terkait kepatutan promosi atas transaksi non-tunai adalah sangat penting dan menarik untuk dikaji lebih lanjut untuk perwujudan keadilan bagi setiap konsumen, termasuk konsumen yang bertransaksi tunai atas peralihan kebijakan pemerintah dari transaksi tunai ke transaksi non-tunai untuk dilakukan penelitian.

Perlindungan konsumen menghadapi tantangan yaitu perkembangan e-commerce (transaksi elektronik) yang terus berkembang cepat seiring dengan perkembangan teknologi telekomunikasi. Badan Perlindungan Sengketa Konsumen (BPSK) sebagai lembaga non-litigasi dan lembaga/forum lain diantaranya Yayasan Lembaga Perlindungan Konsumen Indonesia (YLKI) harus dapat mengikuti perkembangan teknologi telekomunikasi yang maju untuk menghadapi peluang terjadi sengketa yang sangat serius ${ }^{16}$ terkait keamanan dan kerahasiaan atas informasi identitas dan transaksi pemegang kartu beserta dana yang tersimpan. Badanbadan perlindungan konsumen itu harus dapat menaungi sengketa konsumen dan penjual terkait keamanan saat pembayaran transaksi non-tunai, termasuk konsumen yang masih menggunakan metode/cara pembayaran tradisional dengan uang tunai agar tidak diperlakukan secara berbeda (tidak adil) oleh penjual dibandingkan dengan konsumen yang melakukan pembayaran non-tunai (konsumen pemakai kartu). Untuk merefleksikan keadilan hukum yang memberikan perlindungan konsumen dalam berbagai bidang kehidupan manusia, maka pemerintah melalui BI yang bertugas untuk mengawasi bank perlu mengevaluasi bank dan pelaku usaha terkait ketidakpatutan promosi barang dan/jasa oleh penjual (merchant) akibat perbedaan

13 Andre Ata Ujan, Membangun Hukum, Membela Keadilan Filsafat Hukum, (Yogyakarta: Kanisius, 2013), hlm. 27 dan 34.

14 Sudikno Mertokusumo, Mengenal Hukum Suatu Pengantar, (Yogyakarta: Liberty, 1999), hlm. 145.

15 Carto Nuryanto, "Penegakan Hukum Oleh Hakim Dalam Putusannya Antara Kepastian Hukum dan Keadilan", Jurnal Hukum Khaira Ummah Vol. 13, No. 1 (Maret 2018): 71.

16 Arfian Setiantoro, dkk., "Urgensi Perlindungan Hukum Konsumen dan Penyelesaian Sengketa E-Commerce Di Era Masyarakat Ekonomi ASEAN”, Jurnal Rechtsvinding Vol. 7, No. 1, (April 2018): 3. 
cara pembayaran barang dan/jasa yaitu tunai ataukah kartu bahkan harus kartu tertentu yang mengakibatkan konsumen mendapatkan perlakuan diskriminasi (tidak adil).

\section{Pembahasan}

\section{A. Keadilan Bagi Konsumen Yang Bertransaksi Tunai}

Secara ekonomi, konsumen dan pelaku usaha merupakan satu kesatuan yang utuh yang saling mempengaruhi dan saling berkepentingan satu sama lain yang diibaratkan sekeping mata uang. ${ }^{17}$ Konsumen membutuhkan barang dan/jasa yang disediakan oleh pelaku usaha, sedangkan pelaku usaha membutuhkan konsumen untuk menyerap produksinya atau memakai jasanya. Kedudukan pelaku usaha dan konsumen menjadi tidak seimbang dan konsumen berada pada posisi yang lemah, ketika konsumen menjadi objek aktivitas bisnis untuk meraup keuntungan yang sebesar-besarnya oleh pelaku usaha melalui kiat promosi, cara penjualan, serta penerapan perjanjian standar yang merugikan konsumen. ${ }^{18}$ Kerugian konsumen yang muncul karena kesengajaan pelaku usaha tanpa dilandasi itikad baik bertentangan dengan kesusilaan sebagai ketidakpatutan karena menyebabkan pelaku usaha harus bertanggung jawab atas kerugian konsumen. ${ }^{19}$

Berdasarkan tujuan hukum perlindungan konsumen dalam Risalah RUU Perlindungan Konsumen, upaya mewujudkan pembangunan yang memposisikan konsumen sebagai salah satu pelaku ekonomi dan subyek pembangunan. Konsumen harus diposisikan setara dan memiliki posisi tawar sama dengan produsen sebagai salah satu syarat mutlak terwujudnya hubungan hukum yang adil dan jujur. $^{20}$ Tujuan konsumen harus diberikan perlindungan hukum menurut UU Nomor 8 Tahun 1999 adalah untuk meningkatkan harkat dan martabat konsumen perlu meningkatkan kesadaran, pengetahuan, kepedulian, kemampuan dan kemandirian konsumen untuk melindungi diri serta menumbuhkembangkan sikap pelaku usaha yang bertanggung jawab untuk mewujudkan keseimbangan perlindungan kepentingan konsumen dan pelaku usaha yang mengarah terciptanya perekonomian yang sehat. ${ }^{21}$ Keseimbangan antara pelaku usaha dengan konsumen untuk pemenuhan prinsip itikad baik dan keadilan bagi para pihak. ${ }^{22}$ UU Nomor 8 Tahun 1999

17 Sekretariat Jenderal Dewan Perwakilan Rakyat, Proses Pembahasan Rancangan Undang-Undang Tentang Perlindungan Konsumen, (Jakarta: Sekretariat Jenderal Dewan Perwakilan Rakyat, 2001), hlm. 83.

18 Satjipto Rahardjo, Ilmu Hukum, (Bandung: Alumni, 1986), hlm. 164-165. Dalam Susanti Adi Nugroho, Proses Penyelesaian Sengketa Konsumen Ditinjau Dari Hukum Acara Serta Kendala Implementasinya, (Jakarta: Kencana Prenada Media Group, 2008), hlm. 177.

19 M. Syamsudin dan Fera Aditias Ramadani, "Perlindungan Hukum Konsumen Atas Penerapan Klausula Baku: Kajian Putusan Nomor 26/P.BPSK/12/2014, Nomor 15/PDT.G/2015/PN.SBY, dan Nomor 184K/PDT.SUSBPSK/2016," Jurnal Yudisial Vol. 11, No. 1, (April 2018): 96.

20 Sekretariat Jenderal Dewan Perwakilan Rakyat Republik Indonesia, op.cit., hlm. 84.

21 Bagian Menimbang angka 4, angka 5, dan angka 6 UU Nomor 8 Tahun 1999.

22 Celina Tri Siwi Kristiyanti, "Perlindungan Hukum Bagi Konsumen Jasa Keuangan Dalam Perjanjian Baku Dengan Klausula Eksonerasi,” Arena Hukum Vol. 12, No. 2, (Agustus 2019): 357. 
sebagai payung hukum untuk melindungi konsumen terhadap perbuatan tidak jujur dan adil dari pelaku usaha. Usaha konkrit negara untuk melindungi konsumen sesuai konsepsi negara hukum kesejahteraan dalam UUD $1945^{23}$ direfleksikan ke dalam UU Nomor 8 Tahun 1999.

UU Nomor 8 Tahun 1999 sampai saat ini belum mengalami perubahan dan belum dinyatakan bertentangan dengan UUD 1945 dan tidak memiliki kekuatan hukum mengikat oleh MK, karena UU tersebut masih dapat memenuhi kebutuhan hukum masyarakat. ${ }^{24}$ UU Nomor 8 Tahun 1999 juga memiliki berbagai badan perlindungan konsumen yaitu Badan Penyelesaian Sengketa Konsumen (BPSK), Badan Perlindungan Konsumen Nasional (BPKN), dan Lembaga Perlindungan Konsumen Swadaya Masyarakat (misalnya Yayasan Lembaga Konsumen Indonesia (YLKI)), sehingga pendapat fraksi DPR terkait perlindungan konsumen melalui badan perlindungan konsumen telah terangkum dalam UU Nomor 8 Tahun $1999^{25}$ sebagai upaya perlindungan hukum bagi konsumen untuk memperoleh keadilan. Terwujudnya keadilan dalam hubungan konsumen dan pelaku usaha menumbuhkan sikap saling percaya antara konsumen dan pelaku usaha yang dapat menciptakan pasar yang potensial, serta pentingnya sistem peradilan dan peraturan perundang-undang (legislasi) yang memadai sebagai sebagian tugas negara atas perlindungan hak konsumen dalam skala global. ${ }^{26}$

Adanya pemikiran bahwa hak konsumen adalah hak konstitusional. Setiap orang adalah konsumen, maka setiap warga negara Indonesia adalah konsumen. Selaras dengan pemikiran itu, Immanuel Kant berpendapat bahwa hak asasi manusia hanya efektif dalam bingkai konstitusi. ${ }^{27}$ Penghormatan hak asasi terdapat dalam konstitusi, maka dasar hak asasi konsumen diatur juga dalam konstitusi. Pasal 27 ayat (1) UUD 1945 menyebutkan bahwa kesamaan kedudukan setiap warga negara Indonesia dalam hukum dan pemerintahan. Kesederajatan kedudukan antara konsumen dengan pelaku usaha merupakan konsekuensi logis dari kesamaan kedudukan konsumen dan pelaku usaha dalam hukum yang akan mengarahkan kepada keuntungan bagi kedua belah pihak. ${ }^{28}$ Masyarakat sebagai konsumen atas barang/jasa memiliki hak dan kewajiban

23 Ali Mansyur dan Irsan Rahman, "Penegakan Hukum Perlindungan Konsumen Sebagai Upaya Peningkatan Mutu Produksi Nasional", Jurnal Pembaharuan Hukum Vol. II, No. 1, (Januari-April 2015): 3.

24 Pasal 10 ayat (1) huruf e UU Nomor 12 Tahun 2011 diubah dengan UU Nomor 15 Tahun 2019 berbunyi "Material Matan yang harus diatur dengan Undang-Undang berisi:

e. pemenuhan kebutuhan hukum dalam masyarakat."

25 Sekretariat Jenderal Dewan Perwakilan Rakyat, op.cit., hlm. 1135.

26 Elena Anatolyevna Kirillova, etc.,"The Principle of the Consumer Right Protection in Electronic Trade: A Comparative Law Analysis", International Journal of Economics and Financial Issues Vol. 6 Special Issue (S2), (2016): 120.

27 Susan Marks, The Riddle of All Constitustions, 2002. In Ernst-Ulrich Petersmann, "Theories of Justice, Human Rights, and the Constitution of International Markets", Loyola of Los Angeles Law Review Vol. 37, No. 407, (2003): 459.

28 Sekretariat Jenderal Dewan Perwakilan Rakyat, op.cit., hlm. 86. 
yang diatur dalam hukum. Atribut hukum menurut Leopold Pospisil yaitu adanya wewenang, tujuan untuk memperlakukan hukum secara universal, hak dan kewajiban (obligatio), dan sanksi. ${ }^{29}$ Sanksi perlu dicantumkan dalam suatu peraturan perundang-undangan agar dapat ditaati oleh masyarakat. $^{30}$ Sanksi adalah bagian dari paksaan berupa perampasan atau perenggutan secara paksa di luar kemauan yang terkena terhadap segala sesuatu yang dimiliki yakni nyawa, kebebasan, atau harta benda. Hans Kelsen berpendapat ciri hukum positif adalah suatu tatanan yang memaksa (a coercive order). Sanksi tidak hanya berupa hukuman (punishment), tetapi juga ganjaran (reward). ${ }^{31}$ Sanksi (sanksi pidana atau sanksi pemaksa lainnya) menurut A. Hamid S. Attamimi sebagai salah satu ciri yang membedakan norma hukum dengan norma lainnya (adat, agama, dan moral). ${ }^{32}$ Pencantuman sanksi agar hukum "bergigi" bahwa kaidah hukum berupa suruhan (kewajiban) atau larangan akan menjadi pepesan atau garansi kosong, yang kecenderungannya tidak akan dipatuhi sama sekali saat sanksi itu tidak melekat pada hukum. ${ }^{33}$

UU Nomor 8 Tahun 1999 mengatur 9 (sembilan) hak konsumen, 4 (empat) kewajiban konsumen, 5 (lima) hak pelaku usaha, dan 7 (tujuh) kewajiban pelaku usaha, namun diantaranya hak konsumen untuk diperlakukan atau dilayani secara benar, jujur, dan tidak diskriminatif sesuai dengan Pasal 4 ayat (7) UU Nomor 8 Tahun 1999 tidak terdapat sanksi atas pelanggaran hak konsumen tersebut. UU Nomor 8 Tahun 1999 menentukan penjatuhan 2 (dua) macam sanksi berupa sanksi administratif dan sanksi pidana bagi pelaku usaha yang melakukan pelanggaran. Ketiadaan sanksi bagi pelaku usaha yang melanggar hak konsumen tentu saja mengakibatkan terhambatnya pelaksanaan atas perlindungan hak konsumen sebagai ketidakadilan bagi konsumen. Hak konsumen untuk diperlakukan atau dilayani secara benar dan jujur serta tidak diskriminatif sesuai dengan Pasal 4 angka 7 UU Nomor 8 Tahun 1999 menimbulkan kewajiban bagi pelaku usaha untuk memperlakukan atau melayani konsumen secara benar dan jujur serta tidak diskriminatif diatur dalam Pasal 7 huruf c UU Nomor 8 Tahun 1999. Hak konsumen dan kewajiban bagi pelaku usaha yang tidak disertai sanksi bagi pelanggaran hukum oleh pelaku usaha berakibat UU Nomor 8 Tahun 1999 menjadi macan ompong yang tidak melindungi secara maksimal terkait jaminan

29 Soerjono Soekanto, Antropologi Hukum: Materi Pengembangan Ilmu Hukum Adat, (Jakarta: CV. Rajawali, 1984), hlm. 151-157. Dalam Zairin Harahap, "Pengaturan Tentang Ketentuan Sanksi Dalam Peraturan Daerah", Jurnal Hukum No. 1, Vol. 13, (Januari 2006): 44.

30 Ibid., hlm. 39.

31 Bagir Manan, Hukum Positif Indonesia (Suatu Kajian Teoritik), (Yogyakarta: Fakultas Hukum UII Press, 2004), hlm. 8. Dalam Ibid., hlm. 43.

32 Maria Farida Indrati Soeprapto, Ilmu Perundang-undangan: Dasar-dasar dan Pembentukannya, (Yogyakarta: Kanisius, 1998), hlm. 10-11. Dalam Ibid., hlm. 44.

33 Ibid. 
perlakuan secara benar, jujur, dan tidak diskriminatif terhadap konsumen. Perubahan UU Nomor 8 Tahun 1999 sangat diperlukan untuk menyesuaikan dengan kebutuhan hukum masyarakat terkait jaminan perlakuan secara benar, jujur, dan tidak diskriminatif disertai keamanan, kenyamanan, dan keadilan antar konsumen dalam pengunaan teknologi pembayaran secara non-tunai (kartu).

Berbagai manfaat dapat diperoleh oleh pemerintah yang melakukan pembayaran non-tunai untuk mencegah kegiatan pencucian uang, perampokan, menghemat keuangan negara, dan lain-lain bahwa 5 (lima) negara yang banyak melakukan transaksi non-tunai yaitu Belgia, Perancis, Kanada, Inggris, dan Swedia. $^{34}$ Untuk permasalahan selanjutnya adalah kesiapan masyarakat Indonesia untuk melakukan transaksi non-tunai. Kesiapan masyarakat Indonesia seyogianya dilandasi partisipasi masyarakat untuk dilibatkan dalam setiap kebijakan pemerintah (BI) dalam GNNT berupa pemberian masukan secara lisan dan/atau tertulis atas kebijakan pemerintah adalah komitmen pemerintah terhadap Undang-Undang Nomor 12 Tahun 2011 tentang Pembentukan Peraturan Perundang-undangan, ${ }^{35}$ karena masyarakat yang mengetahui kebutuhan mereka sendiri dan berhak mengetahui segala kebijakan pemerintah yang terkait kebutuhan masyarakat melalui partisipasi atau keikutsertaannya dalam pengambilan kebijakan pemerintah. Masyarakat yang berpotensi terkena dampak atas kebijakan itu dan sosialisasi BI atas pelaksanaan GNNT secara berkesinambungan, maka perlu partisipasi masyarakat dan sosialisasi sebagai pemberdayaan masyarakat yang berorientasi kepada upaya memperkuat kemampuan masyarakat dalam memaknai dan memahami wacana yang berkembang, termasuk isu-isu agenda kebijakan pemerintah. ${ }^{36}$ Penumbuhan dan penguatan badan perlindungan konsumen juga sangat diperlukan sebagai instrumen kelembagaan yang dapat menampung aspirasi dan kepentingan masyarakat. ${ }^{37}$ Ketiga langkah telah dilakukan untuk mewujudkan keadilan menurut John Rawls.

Keadilan sebagai tugas dari aturan hukum yang tidak pernah berakhir, yang melengkapi sistem nilai dari seseorang, suatu masyarakat atau umat manusia. ${ }^{38}$ Keadilan menurut Penjelasan Pasal 2 UU Nomor 8 Tahun 1999 adalah partisipasi seluruh rakyat dapat diwujudkan secara maksimal dan memberikan kesempatan kepada konsumen dan pelaku usaha untuk memperoleh haknya

34 Septian Deny,"5 Negara Paling Banyak Bertransaksi Tunai", https://www.liputan6.com/bisnis/read/2138000/5negara-paling-banyak-bertransaksi-non-tunai? utm_expid=.9Z4i5ypGQeGiS7w referrer $=$ https $\% 3 A \% 2 F \% 2 F w w w . g o o g l e . c o m \% 2 F$, diakses 30 Agustus 2019.

9 arwTvQ.0\&utm

35 UU Nomor 12 Tahun 2011 diubah dengan UU Nomor 15 Tahun 2019 tentang Perubahan Atas UU Nomor 12 Tahun 2011 tentang Pembentukan Peraturan Perundang-undangan, yang mulai berlaku tanggal 4 Oktober 2019.

36 Dede Mariana, "Partisipasi Masyarakat Dalam Proses Kebijakan", CosmoGov Vol. 1, No. 2, (Oktober 2015): 228.

37 Ibid.

38 Friedrich supra note 11 at 199. Dalam Petersmann, op.cit., p. 457. 
dan melaksanakan kewajibannya secara adil. Keadilan berdasarkan kerakyatan menurut John Rawls adalah memberikan hak dan kesempatan yang sama atas kebebasan dasar yang seluas-luasnya atas kebebasan yang sama bagi setiap orang dan mampu mengatur kembali kesenjangan sosial ekonomi yang dapat memberikan keuntungan yang bersifat timbal balik (reciprocal benefits) bagi setiap orang. ${ }^{39}$ Keadilan sosial sebagai pemenuhan hak sosial yang menjamin akses terhadap sumber kebutuhan yang terkait martabat seseorang. ${ }^{40}$ Keadilan dapat direfleksikan terhadap kesenjangan dalam masyarakat melalui koreksi dan perbaikan kondisi ketimpangan yang dialami kaum lemah melalui institusi-institusi sosial, ekonomi, dan pemberdayaan, serta setiap aturan sebagai pemandu untuk mengembangkan kebijakan untuk mengkoreksi ketidakadilan bagi kaum lemah. $^{41}$ Keadilan diartikan memberikan perlakuan yang sama kepada setiap orang, dengan pengecualian jika terdapat alasan yang membenarkan untuk memperlakukan secara tidak sama. ${ }^{42}$

Kebijakan terkait sistem pembayaran adalah salah satu bidang tugas BI yaitu menjaga kelancaran sistem pembayaran tunai dan non-tunai. Sistem pembayaran non-tunai yang merupakan kewajiban bagi BI sebagai pemegang otoritas sistem pembayaran di Indonesia untuk memastikan bahwa sistem pembayaran non-tunai dapat berjalan secara aman, efisien, dan andal. ${ }^{43}$ BI memiliki tugas dalammelaksanakanGNNTmemilikipedoman berdasarkan Pasal 44 ayat (1) dan Pasal 44 ayat (2) PBI Nomor 19/8/PBI/2017 berwenang untuk menetapkan kebijakan tertentu dalam melakukan penetapan dan/atau memberikan persetujuan penyelenggara GPN atas dasar pertimbangan untuk bahwa seharusnya (das sollen) sejumlah kebijakan pemerintah dapat memberikan keadilan bagi masyarakat, tetapi senyatanya (das sein) sejumlah kebijakan tersebut merugikan masyarakat sebagai konsumen yang menggunakan transaksi tunai. Keadilan bagi seluruh konsumen seyogianya memperlakukan hal yang sama kepada setiap konsumen (konsumen tunai dan konsumen non-tunai), bukan kepada konsumen tertentu (konsumen non-tunai pemakai kartu tertentu) yaitu penjual menyediakan promosi yang patut bagi setiap konsumen. Permasalahan selanjutnya adalah promosi seperti apakah yang dapat dikatakan sebagai patut. Hal itu disebabkan promosi yang patut menjadi

39 Muhammad Syukri Albani Nasution, dkk., Hukum Dalam Pendekatan Filsafat, (Jakarta: Kencana, 2015), hlm. 318.

40 Petersmann, op.cit., p. 459.

41 Nasution, dkk., op.cit.

42 Franz von Magnis, Etika Umum: Masalah-masalah Pokok Filsafat Moral, (Yogyakarta: Kanisius, 1984), hlm. 103-104. Dalam Mardian Wibowo, Kebijakan Hukum Terbuka Dalam Putusan Mahkamah Konstitusi Konsep dan Kajian Dalam Pembatasan Kebebasan Pembentuk Undang-Undang, (Depok: PT. RajaGrafindo Persada, 2019), hlm. 69.

43 Mika Hastuti Br. Sianturi dan Suhadak, "Analisis Pengaruh GNNT (Gerakan Nasional Non Tunai) Terhadap Nilai Transaksi Nasabah dan Dampaknya Terhadap Makroekonomi Indonesia (Studi pada Bank Indonesia Tahun 2014-2018)", Jurnal Administrasi Bisnis Vol. 70, No. 1, (Mei 2019): 54-55. 
bagian terpenting bagi pelaku usaha untuk menawarkan produknya sesuai etika dan moral bertransaksi, yang akan menimbulkan kepercayaan dan jaminan perlindungan terhadap konsumen. ${ }^{44}$

\section{B. Kepatutan Promosi Atas Transaksi Non-Tunai Di Masa Mendatang}

Indonesia sebelumnya masih tertinggal dibandingkan negara tetangga yaitu Malaysia dan Singapura dalam pembayaran ritel dengan menggunakan kartu. Berdasarkan data Mastercard dan Global Payment Summit tahun 2013, Indonesia pada kelompok negara yang transaksi non-tunai kurang dari 30\% kalah dengan 3 negara yaitu Singapura, Malaysia, dan Thailand. ${ }^{45}$ Menurut Direktur Eksekutif Indonesia Information and Communication Technology (ICT), penggunaan uang tunai di Indonesia masih sekitar 75\% dan Meksiko sebagai negara berkembang berhasil meningkatkan transaksi non-tunai menjadi 53\% dari total transaksi, ${ }^{47}$ sedangkan transaksi non-tunai di Belanda sekitar $85 \%$ dari total transaksi ritel, ${ }^{48}$ dan Korea Selatan bertransaksi non-tunai sekitar 70\%. ${ }^{49}$ Jepang pernah menjadi pelopor transaksi non-tunai, namun jauh tertinggal dengan banyak negara lain yang menerapkan pembayaran elektronik. Jumlah populasi orang tua sangat banyak yang lebih menyukai transaksi uang fisik daripada non-tunai dan tidak ada kejahatan pemalsuan uang berakibat masyarakat nyaman membawa uang tunai. ${ }^{50}$

Segmentasi terbesar transaksi non-tunai di Indonesia adalah masyarakat kelas menengah ke bawah. ${ }^{51}$ Pada daerah-daerah pelosok yang tidak terjangkau layanan perbankan, masyarakat masih beranggapan lebih aman menyimpan uang di rumah melalui kepemilikan akun bank yang masih sedikit. $^{52}$ Kehadiran uang elektronik dapat meningkatkan inklusi keuangan masyarakat, terutama banyak masyarakat yang tidak terjangkau oleh bank (unbankable). ${ }^{53}$ Keadaan jauh berbeda di tahun 2017, pembayaran non-tunai di Tiongkok semakin pesat dengan

44 Ambar Wariati dan Nani Irma Susanti, "E-Commerce Dalam Perspektif Perlindungan Konsumen," Jurnal Ekonomi dan Bisnis Vol. 1, No. 2, (November 2014), tanpa halaman.

45 Susiati Dewi, "Prospek Pembayaran Non Tunai. Dalam Gerai Info Bank Indonesia". Dalam "Kreatif Menginisiasi Transaksi Non Tunai”, Newsletter Bank Indonesia, Ed. 50 Tahun 5 (2014): 10.

46 Ulfa Arieza, "Perang Diskon dan Masa Depan Uang Elektronik", https://www.cnnindonesia. com/ekono mi/20190705122825-92-409395/perang-diskon-dan-masa-depan-uang-elektronik, diakses 23 Oktober 2019.

47 Newsletter Bank Indonesia, op.cit., hlm. 9.

48 Ibid., hlm. 8.

49 Ibid.

50 CNN Indonesia, "Sempat Pelopori Uang Elektronil, Kini Jepang Jauh Tertinggal", https:/www.cnnindonesia. com/ekonomi/20190821152359-78-423418/sempat-pelopori-uang-elektronik-kini-jepang-jauh-tertinggal, diakses 23 Oktober 2019.

51 Kompasiana, "Edukasi Transaksi Non Tunai", https://www.kompasiana.com/aidaramli/555805a8b 67e61925b66c09e/edukasi-transaksi-non-tunai, diakses 21 Oktober 2019.

52 Kompasiana, "Sosialisasi Gerakan Nasional (GNNT) Pentingkah?”, https:/www.kompasiana. com/ muttaqin98/5bf532acab12ae5d6a2ed685/sosialisasi-gerakan-nasional-non-tunai-gnnt-pentingkah?page=all, diakses 23 Oktober 2019.

53 Ibid. 
dukungan infrastruktur, teknologi, dan internet yang meluas tercipta cashless society secara global. Keadaan itu berpengaruh terhadap Indonesia ${ }^{54}$ pada tahun 2019 dengan alasan transaksi non-tunai dinilai meyakinkan dan aman bagi konsumen melalui satu aplikasi pembayaran, tanpa perlu membawa uang tunai yang banyak. ${ }^{55}$

Tantangan terbesar dalam GNNT adalah manusia itu sendiri yaitu resistensi terhadap perubahan atau kemajuan teknologi, perilaku penggunaan alat pembayaran non-tunai yang kurang bijak, dan tindak kriminal yang marak kepada pengguna alat pembayaran non-tunai dan membangun infrastruktur yang memadai untuk memperluas layanan keuangan sampai ke pelosok Indonesia dan terbuka kesetaraan dan kesempatan untuk memperoleh layanan yang sama antar berbagai wilayah. ${ }^{56}$ Upaya yang mendorong GNNT adalah edukasi perilaku, harmonisasi regulasi antar pemangku kepentingan dengan pengguna layanan, perbaikan sistem pengawasan dan implementasi di lapangan, dan perbaikan sistem perlindungan konsumen. Edukasi atau pendidikan berperan penting agar manusia memiliki pengetahuan dan wawasan terkait kegiatan ekonomi bahwa setiap orang dapat mengelola uangnya dengan baik dan mendapatkan kemudahan saat menggunakan transaksi non-tunai. ${ }^{57}$ Belanda dalam mendorong masyarakat untuk meninggalkan transaksi tunai adalah menciptakan lingkungan yang nyaman untuk bertransaksi secara non-tunai berupa potongan harga khusus, fasilitas istimewa, dan hadiah-hadiah menarik yang diberikan kepada masyarakat yang berbelanja menggunakan kartu debet dan kartu kredit. Pemerintah Belanda juga secara tegas melarang penggunaan uang tunai dalam transaksi di toko tertentu yang rawan tindakan kriminal, sedangkan di bidang industri terdapat penghargaan dan penyelenggaraan kompetisi untuk pedagang yang mempromosikan pembayaran non-tunai. ${ }^{58}$

Menurut Bhima Yudistira Adhinegara (Peneliti Institute For Development Of Economics \& Finance (INDEF)), transaksi kartu hanya akan menguntungkan segelintir pihak yaitu sekelompok institusi jasa keuangan dan berpotensi terhadap Pemutusan Hubungan Kerja (PHK) dan kerugian

54 Yenny Yusra, "Potensi Perluasan "Cashless Society" di Indonesia," https://dailysocial.id/post/potensiperluasan-cashless-society-di-indonesia, diakses 28 November 2020.

55 Elsa Catriana, "Studi: Transaksi Nontunai di Indonesia Capai 128 Triliun pada 2019," https://money. kompas.com/read/2020/01/15/130200026/studi--transaksi-nontunai-di-indonesia-capai-rp-128-triliun-pada2019?page=all, diakses 28 November 2020.

56 Kompasiana, "Peluang, Tantangan, dan Upaya Mendorong Gerakan Nasional Non Tunai (GNNT) Di Indonesia", https://www.kompasiana.com/annisanurulkoesmarini/557dla738efdfdeb6ff37aa6/peluangtantangan-dan-upaya-dalam-mendorong-gerakan-nasional-non-tunai-gnnt-di-indonesia?page=all, diakses 21 Oktober 2019.

57 R.T. Shinta Ayu dan Cahyono Hendry, Studi Penggunaan Media Pembelajaran Ekonomi Pada Materi Uang dan Bank Kelas X SMA Negeri 1 Magetan, 2016. Dalam Putri Ratna Nelasari, dkk., ”Pengaruh Sistem Transaksi Non Tunai Terhadap Tingkat Konsumsi Masyarakat Di Surabaya”, Jurnal Ekonomi Islam Vol. 1, No. 2, (2018): 167.

58 Newsletter Bank Indonesia, op.cit., hlm. 8. 
konsumen. Kebijakan gerbang tol otomatis yang menerapkan transaksi tol non-tunai di jalan diatur dalam Peraturan Menteri Pekerjaan Umum dan Perumahan Rakyat Nomor 16/ PRT/M/2017 tentang Transaksi Tol Nontunai di Jalan Tol. Kebijakan itu bertujuan untuk memberikan pelayanan kepada pengguna jalan tol yang efektif, efisien, aman dan nyaman. Hal itu mempermudah aksesibilitas jalan tol dan memangkas waktu layanan transaksi di gerbang tol dan upaya mengatasi kemacetan di gerbang tol akibat volume lalu lintas kendaraan yang tinggi. Mekanisme isi ulang kartu tol berbayar itu berlawanan dengan kondisi perekonomian yang sedang lesu. Daya beli yang lesu berdampak kepada masyarakat miskin. Isi ulang kartu tol akan dikenakan charge akan langsung mengoreksi daya beli dan pendapatan masyarakat yang berakibat kontra produktif dengan perekonomian. ${ }^{59}$ Transaksi non-tunai memiliki berbagai keuntungan, tetapi di sisi lain, ada beberapa kerugian diantaranya potensi gangguan jaringan teknologi yang mengganggu keuangan penggunanya dan penggunanya menjadi konsumtif akibat kemudahan akses dan berbagai tawaran promosi yang menarik. ${ }^{60}$

Dasar atas kebijakan tertentu berdasarkan pertimbangan untuk meningkatkan efisiensi nasional, mendukung kebijakan nasional, menjaga kepentingan publik, menjaga pertumbuhan industri dan persaingan usaha yang sehat. Dengan demikian, pelaku usaha dengan pihak yang terhubung dengan GPN (NPG) yaitu bank umum, bank umum syariah, dan lembaga selain bank harus melakukan kerjasama berupa promosi kepada konsumen tanpa merugikan konsumen. Bank melalui penjual menerapkan promosi yang sama terhadap setiap pemegang kartu bukan terhadap kartu tertentu bahwa seluruh kegiatan promosi itu diawasi oleh BI yang berkoordinasi badan perlindungan konsumen secara terus-menerus sampai masyarakat dapat secara bijak memilih cara pembayaran non-tunai. Untuk penegakan hukum secara efektif perlu mengutamakan keadilan terlebih dahulu untuk mencegah kesenjangan perlakuan secara adil yang terjadi dalam masyarakat. Setelah keadilan tercapai, maka kebijakan dapat diterapkan untuk dapat memberikan manfaat kepada masyarakat secara keseluruhan.

Kepatutan menurut Pitlo hendaknya memperhatikan kepentingan orang yang dirugikan. ${ }^{61}$ G.W. Paton juga mengemukakan mengenai teori kepatutan hukum (equity of law theory) bahwa kepatutan (equity) pada pelaksanaannya tidak berlawanan dengan hukum, tetapi pengaruhnya semakin kuat

59 M. Dani Pratama Huzaini, "Menelaah Dampak kebijakan Transaksi Non Tunai”, https://www.hukumonline. $\mathrm{com} /$ berita/baca/lt59eeee27121aa/menelaah-dampak-kebijakan-transaksi-non-tunai/, diakses 18 Oktober 2019.

60 CNN Indonesia, "Waspada Bahaya mengintai di Era Cashless Society", https://www.cnnindonesia.com/ek onomi/20190308142700-83-375574/waspada-bahaya-mengintai-di-era-cashless-society, diakses 18 Oktober 2019.

61 Adery P. Winter, "Perlindungan Hak-hak Konsumen Terhadap Penggunaan Produk Provider Telekomunikasi Di Indonesia”, Jurnal Hukum Unsrta Vol. XXI, Ed. Khusus, No. 4, (April-Juni 2013): 64. 
dalam penyelesaian suatu sengketa saat aspek hukum tidak mengatur. ${ }^{62}$ W. Friedman dan Aristoteles juga mengaitkan antara kepatutan dengan keadilan bahwa keadilan terbagi menjadi keadilan hukum, keadilan alam, keadilan abstrak, dan kepatutan. ${ }^{63}$ Kepatutan dalam sistem civil law akan membantu dalam perumusan penyalahgunaan hak, yang semula hanya dibatasi pada pelanggaran undangundang (hukum) dan perkembangannya berdasarkan pada nilai-nilai kepatutan (equity). Kepatutan tidak untuk mengubah atau mengurangi keadilan hukum, tetapi sebatas mengoreksi atau melengkapi dalam keadaan individu tertentu serta kondisi kasus tertentu. Keadilan tertinggi adalah ketidakadilan tertinggi (summa iustitia summa injuria) ${ }^{64}$ tidak akan terjadi, karena nilai keadilan dalam hubungan antara individu dikembalikan pada proporsi sewajarnya. ${ }^{65}$ Berdasarkan pemikiran itu, kepatutan terkait dengan keadilan yang luwes sesuai kebutuhan masyarakat dan hubungan antara individu pada proporsi yang sewajarnya.

Kepatutan dalam transaksi terkait dengan definisi manfaat, adil, dan kepastian hukum sebagaimana pendapat Gustav Radburch terdapat dalam asas perlindungan konsumen pada Pasal 2 UU Nomor 8 Tahun 1999 bahwa perlindungan konsumen berasaskan manfaat, keadilan, keseimbangan, keamanan dan keselamatankonsumen, sertakepastian hukum. Asas manfaat berdasarkan Penjelasan Pasal 2 UU Nomor 8 Tahun 1999 dimaksudkan untuk mengamanatkan bahwa segala upaya dalam penyelenggaraan perlindungan konsumen harus memberikan manfaat sebesar-besarnya bagi kepentingan konsumen dan pelaku usaha secara keseluruhan, asas keadilan berdasarkan Penjelasan Pasal 2 UU Nomor 8 Tahun 1999 dimaksudkan agar partisipasi seluruh rakyat dapat diwujudkan secara maksimal dan memberikan kesempatan kepada konsumen dan pelaku usaha untuk memperoleh haknya dan melaksanakan kewajibannya secara adil, asas keseimbangan menurut Penjelasan Pasal 2 UU Nomor 8 Tahun 1999 untuk memberikan keseimbangan antara kepentingan konsumen, pelaku usaha, dan pemerintah dalam arti materiil ataupun spiritual, asas keamanan dan keselamatan konsumen berdasarkan Penjelasan Pasal 2 UU Nomor 8 Tahun 1999 dimaksudkan untuk memberikan jaminan atas keamanan dan keselamatan kepada konsumen dalam penggunaan, pemakaian dan pemanfaatan barang dan/atau jasa yang

62 Agus Yudha Hernoko, Hukum Perjanjian (Asas Proporsionalitas Dalam Kontrak Bisnis), (Jakarta: Kencana, 2013), hlm. 66. Dalam Abdul Hadi, "Fenomena Menikah Dengan Teman Sekantor Pasca Putusan Mahkamah Konstitusi Tentang Uji Materi Pasal 153 ayat (1) huruf f Undang-Undang Nomor 13 Tahun 2003 Tentang Ketenagakerjaan”, Jurnal Surya Kencana Dua: Dinamika Masalah Hukum dan Keadilan Vol. 5, No. 1, (Juli 2018): 357 .

63 R. Arry Mth. Soekowathy, "Fungsi dan Relevansi Filsafat Hukum bagi Rasa Keadilan dalam Hukum Positif," Jurnal Filsafat, Jilid 35 No. 3 Desember 2003, hlm. 291. Dalam Dian Agung Wicaksono, ’Peran Mahkamah Konstitusi Dalam Mewujudkan Fair Equality of Opportunity di Indonesia (Analisis Putusan Nomor 117/PUUVII/2009)," Jurnal Konstitusi Vol. 9, No. 1, (Maret 2012): 91.

64 Franz Magnis Suseno, Etika Politik: Prinsip Moral Dasar Kenegaraan Modern, (Jakarta: PT. Gramedia Pustaka Utama, 2016), hlm. 103.

65 Hernoko, Ibid., hlm. 67. Dalam Ibid. 
dikonsumsi atau digunakan, dan asas kepastian hukum berdasarkan Penjelasan Pasal 2 UU Nomor 8 Tahun 1999 dimaksudkan agar baik pelaku usaha maupun konsumen menaati hukum dan memperoleh keadilan dalam penyelenggaraan perlindungan konsumen, serta negara menjamin kepastian hukum. Ketika promosi yang dilakukan oleh penjual barang dan/atau jasa dilakukan sesuai dengan asas perlindungan konsumen, maka promosi harus mengandung kepatutan.

Kepatutan berdasarkan etimologi sebagai kepantasan, kelayakan, kesesuaian, kecocokan, segala yang dilakukan hendaknya sesuai dengan batas-batas yang berlaku dalam masyarakat. ${ }^{66}$ Terkait kepatutan atas promosi, kepatutan itu harus dikaitkan dengan definisi promosi dalam Pasal 1 angka 6 UU Nomor 8 Tahun 1999, yaitu:

- pengenalan atau penyebarluasan informasi suatu barang dan/atau jasa;

- untuk menarik minat beli konsumen terhadap barang dan/atau jasa yang akan dan sedang diperdagangkan.

untuk menarik minat beli konsumen, promosi yang dilakukan penjual harus jujur, dan adil (tidak diskriminatif) terhadap barang dan/jasa dan cara pembayarannya oleh setiap konsumen, sehingga tidak merugikan konsumen. Kepatutan dalam promosi oleh pelaku usaha adalah kegiatan pengenalan atau penyebarluasan informasi suatu barang dan/ atau jasa untuk menarik minat beli konsumen terhadap barang dan/atau jasa yang akan dan sedang diperdagangkan, ketika:

- produksi dan/atau perdagangan atas barang dan/atau jasa sesuai dengan janji (Pasal 8 ayat (1) huruf f UU Nomor 8 Tahun 1999);

- barang dan/atau jasa itu sesuai dengan yang dipromosikan (Pasal 9 ayat (1) UU Nomor 8 Tahun 1999);

- tidak membuat pernyataan yang tidak benar atau menyesatkan terkait barang dan/atau jasa mengenai harga atau tarif, kegunaan, kondisi, tanggungan, jaminan, hak atau ganti rugi, tawaran potongan harga atau hadiah menarik yang ditawarkan, dan bahaya penggunaannya (Pasal 10 UU Nomor 8 Tahun 1999);

- promosi dengan harga atau tarif khusus dalam waktu dan jumlah tertentu, jika tidak bermaksud untuk melaksanakannya sesuai dengan waktu dan jumlah yang dipromosikan (Pasal 12 UU Nomor 8 Tahun 1999);

- menjanjikan pemberian hadiah berupa barang dan/atau jasa lain secara cuma-cuma dengan maksud tidak memberikannya atau memberikan tidak sebagaimana yang dijanjikannya (Pasal 13 ayat (1) UU Nomor 8 Tahun 1999); dan

- promosi obat, obat tradisional, suplemen makanan, alat kesehatan, dan jasa pelayanan kesehatan dengan cara menjanjikan pemberian hadiah berupa

66 Kamus Besar, ”Kepatutan," http://kamusbesar.com, diakses 28 Juli 2015. Dalam Sulaeman, ”Asas Kepatutan Dalam Tanggung Jawab Sosial dan Lingkungan pada Perseroan," Badamai Law Journal Vol. 1, Issues 1, (April 2016): 63 . 
barang dan/atau jasa lain (Pasal 13 ayat (2) UU Nomor 8 Tahun 1999).

Promosi terkait produk memiliki keterbukaan sebagai salah satu sendi pokok pengaturan perlindungan hukum bagi konsumen. ${ }^{67}$ Kepatutan atas promosi itu juga harus dikaitkan dengan kewajibannya sebagai pelaku usaha untuk: (1) beritikad baik dalam melakukan kegiatan usahanya (Pasal 7 huruf a UU Nomor 8 Tahun 1999); (2) memberikan informasi yang benar, jelas dan jujur mengenai kondisi dan jaminan barang dan/atau jasa serta memberi penjelasan penggunaan, perbaikan dan pemeliharaan (Pasal 7 huruf b UU Nomor 8 Tahun 1999); memperlakukan atau melayani konsumen secara benar dan jujur serta tidak diskriminatif (Pasal 7 huruf c UU Nomor 8 Tahun 1999); menjamin mutu barang dan/atau jasa yang diproduksi dan/atau diperdagangkan berdasarkan ketentuan standar mutu barang dan/atau jasa yang berlaku (Pasal 7 huruf d UU Nomor 8 Tahun 1999); memberi kesempatan kepada konsumen untuk menguji, dan/atau mencoba barang dan/atau jasa tertentu serta memberi jaminan dan/atau garansi atas barang yang dibuat dan/atau yang diperdagangkan (Pasal 7 huruf e UU Nomor 8 Tahun 1999); memberi kompensasi, ganti rugi dan/atau penggantian atas kerugian akibat penggunaan, pemakaian dan pemanfaatan barang dan/atau jasa yang diperdagangkan (Pasal 7 huruf $\mathrm{f}$ UU Nomor 8 Tahun 1999); dan memberi kompensasi, ganti rugi dan/atau penggantian apabila barang dan/atau jasa yang dterima atau dimanfaatkan tidak sesuai dengan perjanjian (Pasal 7 huruf g UU Nomor 8 Tahun 1999). Kepatutan atas promosi dalam transaksi pada dasarnya ditujukan untuk kepentingan bagi setiap konsumen yaitu keadilan termasuk konsumen transaksi tunai. Konsumen harus diperlakukan atau dilayani secara benar, jujur, dan tidak diskriminatif (adil) oleh penjual (merchant), yaitu memperlakukan hal yang sama (promosi, harga, sikap, pernyataan, informasi, dan janji) kepada setiap konsumen, termasuk cara pembayaran barang dan/jasa. Tujuan dari kepatutan promosi dalam transaksi adalah keadilan bagi setiap konsumen untuk membayar dengan harga yang sama atas barang dan/jasa dan penjual berlaku patut dalam promosinya yang menciptakan penghargaan atas harkat dan martabat seseorang dalam transaksi.

Berdasarkan Surat Badan Perlindungan Konsumen Nasional (BPKN) Nomor 10/ BPKN/09/2017 perihal Rekomendasi Terkait Kebijakan Gerbang Pembayaran Nasional tanggal 22 September 2017 bahwa GNNT memerlukan tahapan proses, program, dan upaya untuk meningkatkan pemahaman dan keterlibatan masyarakat, dunia usaha, dan pemerintah secara menyeluruh. Oleh karenanya, BPKN merekomendasikan beberapa hal kepada Gubernur BI bahwa kebijakan non-tunai perlu daya jangkau terapan jauh ke depan, mengarah kepada

67 A. Zen Umar Purba, "Perlindungan Konsumen: Sendi-sendi Pokok Pengaturan, Hukum dan Pembangunan, Tahun XXII (Agustus 1992): 393-408. Dalam Abdul Halim Barkatullah, "Urgensi Perlindungan Hak-hak Konsumen Dalam Transaksi di E-Commerce,” Jurnal Hukum No. 2, Vol. 14, (April 2007): 255. 
efisiensi dan kepraktisan sebagai alat transaksi masyrakat termasuk intergrasi dengan kartu lain yang berfungsi sejenis, konsumen tetap memiliki alternatif akses tunai dan non-tunai, konsumen tetap memiliki akses pembayaran tunai sesuai Undang-Undang Nomor 7 Tahun 2011 tentang Mata Uang yang masih berlaku, dan semua bentuk pengaturan mengedepankan kepentingan dan keadilan bagi konsumen. UU Nomor 7 Tahun 2011 selanjutnya ditetapkan berdasarkan amanat dari konstitusi yaitu Pasal 23B UUD 1945 yang menyatakan "Macam dan harga mata uang ditetapkan dengan Undang-Undang”. Berdasarkan Pasal 1 angka 2 UU Nomor 7 Tahun 2011 dinyatakan bahwa uang adalah alat pembayaran yang sah dan uang rupiah sebagai mata uang sebagai salah satu simbol kedaulatan negara yang harus dihormati dan dibanggakan oleh seluruh warga negara Indonesia dan diperlukan untuk mewujudkan kesejahteraan sosial bagi seluruh rakyat Indonesia.

Rupiah sebagai wujud mata uang bangsa Indonesia merupakan bukti fisik kehadiran uang berdasarkan UUD 1945 dan UU Nomor 7 Tahun 2011. Kehadiran uang tunai (cash) masyarakat Indonesia sangatlah penting terkait simbol kedaulatan negara, alat pembayaran, dan membantu pemerintah dalam mewujudkan salah tujuan negara yaitu mencapai kesejahteraan sosial seluruh rakyat Indonesia. Kehadiran uang rupiah adalah tidak main-main dan tidak dapat dilaksanakan secara tergesa-gesa untuk mengubah kebiasaan masyarakat melakukan pembayaran menjadi non-tunai. Kepercayaan masyarakat Indonesia terhadap rupiah akan berdampak terhadap kepercayaan masyarakat internasional terhadap rupiah dan perekonomian nasional, ${ }^{68}$ maka uang rupiah merupakan salah satu simbol kedaulatan negara yang harus dihormati dan dibanggakan oleh seluruh warga negara Indonesia. Manajemen sistem pembayaran dan pengelolaan uang untuk mendorong ketersediaan uang rupiah berkualitas dan terpercaya, distribusi dan pengolahan uang yang aman dan optimal, serta layanan kas yang prima merupakan tugas dari BI. Kebutuhan rupiah agar tercukupi di masyarakat dan mendorong penggunaan rupiah di seluruh wilayah Indonesia dalam mendorong aktivitas ekonomi yang lebih stabil dan seimbang merupakan komponen vital bagi kelangsungan perekonomian nasional dan eksistensi rupiah sebagai lambang kedaulatan bangsa ${ }^{69}$ Tugas BI tersebut akan berkontradiksi dengan GNNT sebagai kebijakan BI untuk mengarahkan transaksi masyarakat dari tunai ke transaksi non-tunai menyebabkan masyarakat pada generasi mendatang tidak akan mengenal fisik uang rupiah dan mengurangi martabat rupiah sebagai simbol kedaulatan negara yang harus dihormati dan dibanggakan seluruh warga negara Indonesia dan bahkan masyarakat Internasional. Uang tunai berperan sebagai salah satu simbol yang paling bertahan lama

68 Dede Rosyadi, "Menjaga Rupiah Sebagai Simbol Kedaulatan NKRI”, https://www.merdeka.com/uang/ menjaga-rupiah-sebagai-simbol-kedaulatan-nkri.html, diakses 28 Oktober 2019.

69 Ibid. 
dan tersebar luas dalam masyarakat sampai saat ini untuk dapat bertahan di era digital. ${ }^{70}$

Kehadiran uang rupiah sebagai uang tunai di Indonesia juga berperan sebagai partisipasi dalam perwujudan kesejahteraan sosial bagi seluruh rakyat Indonesia. Uang dapat memenuhi kondisi terpenuhinya kebutuhan material, spiritual, dan sosial warga negara agar dapat hidup layak dan mampu mengembangkan diri, sehingga dapat melaksanakan fungsi sosialnya (Pasal 1 angka 1 Undang-Undang Nomor 11 Tahun 2009 tentang Kesejahteraan Sosial). Uang sebagai dukungan dalam salah satu bentuk partisipasi sebagaimana dikemukakan oleh Talizidu Ndraha bahwa bentuk partisipasi dikelompokkan dalam 5 (lima) bentuk dukungan, yakni buah pikiran, keterampilan, tenaga, harta benda, dan uang. ${ }^{71}$ Uang memiliki berbagai peranan dalam kehidupan manusia yang menciptakan transaksi yang didalamnya terdapat komunikasi antar manusia sebagaimana pendapat dari William I. Gorodn bahwa komunikasi adalah suatu transaksi dinamis yang melibatkan gagasan dan perasaan, yang berfungsi sebagai komunikasi sosial untuk membangun konsep diri kita, aktualisasi diri, kelangsungan hidup, memperoleh kebahagiaan, terhindar dari tekanan dan ketegangan; komunikasi ekspresif untuk menyampaikan perasaanperasaan (emosi); komunikasi ritual dalam suatu komunitas untuk melakukan upacaraupacara berlainan sepanjang tahun dan sepanjang hidup; dan komunikasi instrumental yang bertujuan untuk menginformasikan, mengajar, mendorong, mengubah sikap, menggerakkan tindakan, dan menghibur, ${ }^{72}$ sehingga ketidakhadiran uang menyebabkan hidup manusia menjadi semakin jauh dari kesejahteraan. Manfaat uang dalam kehidupan manusia antara lain melatih untuk menjalankan pola hidup hemat hidup yang lebih hemat, berlatih untuk lebih tertib dan teratur, mengurangi stres melalui pengelolaan keuangan dengan baik, memiliki perencanaan masa depan yanglebih baik tanpa permasalahan hutang, memiliki perlindungan dari kejadian yang tidak terduga, menghindarkan diri dari utang melalui pembayaran tunai, dan sedekah yang terkait dengan mengasah rasa sosial kemanusiaan, kebahagian dan kepuasan. ${ }^{73}$

Uang memiliki arti yang sangat penting bagi manusia ${ }^{74}$ untuk dapat memenuhi

70 Nick Llewellyn, "'Money Talks': Communicative and Symbolic Functions of Cash Money,” Sage Journals Vol. 50, Issue 4, (2016): 796.

71 Talizidu Ndraha, Pembangunan Masyarakat, Mempersiapkan Masyarakat Tinggal Landas, (Jakarta: Rineka Cipta, 1990). Dalam Gunawan Muhtar, Kontribusi Organisasi Sosial Dalam Pembangunan Kesejahteraan Sosial, (Jakarta: P3KS Press (Anggota IKAPI), 2010), hlm. 23.

72 Deddy Mulyana, Ilmu Komunikasi: Suatu Pengantar, (Bandung: Rosda, 2005), hlm. 5-30. Dalam Tutut Handayani, "Membangun Komunikasi Efektif Untuk Meningkatkan Kualitas Dalam Proses belajar mengajar", Ta'dib Vol. XVI, No. 02, (November 2011): 280-284.

73 Kompas.com, "7 Manfaat Mengelola Keuangan Dengan Baik", https://money.kompas.com/ $\mathrm{read} / 2016 / 11 / 15 / 052648726 / 7 . m a n f a a t . m e n g e l o l a . k e u a n g a n . d e n g a n . b a i k$ ?page=all, diakses 28 Oktober 2019.

74 Wasiaturrahma, etc., "Non Cash Payment and Demand for Real Money in Indonesia," Journal of Economics, Business, and Accountancy Ventura Vol. 22, No. 1, (April-July 2019): 1. 
kebutuhan material, spiritual, dan sosial dalam hidup layak dan mampu mengembangkan dirinya, yang dapat menimbulkan kebahagiaan, rasa kemanusiaan, dan kepuasan bagi dirinya sendiri dan orang lain. Pengaturan pemerintah untuk masa mendatang harus memperhitungkan kelemahan dan kelebihan transaksi tunai dan transaksi non-tunai secara seksama untuk mengedepankan martabat atas keberadaan uang rupiah dan kesejahteraan sosial bagi seluruh rakyat Indonesia sebagai sistem perlindungan konsumen yang berkeadilan bagi konsumen dan pelaku usaha. Terkait pelaksanaan GNNT, budaya baik dalam masyarakat melalui fisik uang akan sangat sayang sekali terkikis, yaitu nilai ekonomi-keuangan melalui kegiatan berhemat (menabung uang) dan nilai sosial dan kemanusiaan melalui sumbangan fakir miskin dan menghargai uang, maka pemerintah seyogianya mempertimbangkan secara seksama nilai-nilai baik yang telah tumbuh dalam masyarakat Indonesia.

Perlunya pemberdayaan konsumen sebagaimana Penjelasan Umum UU Nomor 8 Tahun 1999 bahwa kebebasan untuk memilih aneka jenis dan kualitas barang dan/atau jasa sesuai dengan keinginan dan kemampuan konsumen, seyogianya dibarengi dengan perlakuan setara bagi konsumen dalam memilih cara pembayaran oleh penjual. GNNT tanpa keadilan bagi konsumen tunai dan non-tunai untuk memberlakukan promosi yang sama kepada setiap konsumen pemegang kartu (bukan pemegang kartu tertentu) akan memperlakukan konsumen secara sama dan melaksanakan penuh atas kebijakan BI itu. Dengan demikian, kedudukan pelaku usaha dan konsumen menjadi menjadi seimbang dan konsumen tidak berada pada posisi yang lemah. Konsumen tidak menjadi objek aktivitas bisnis untuk meraup keuntungan sebesar-besarnya oleh pelaku usaha melalui kiat promosi, cara penjualan, dan perjanjian standar yang merugikan konsumen.

RUU Perlindungan Konsumen di masa mendatang mengubah paradigma konsumen agar persepsi konsumen terhadap pelaku usaha tidak lagi menjadi negatif, tetapi juga perlindungan terhadap pelaku usaha yang baik berupa pemisahan pengaturan antara pelaku usaha barang dan penyedia jasa, Standar Nasional Indonesia (SNI) terkait barang untuk penyedia jasa, ketentuan mengenai penyedia jasa komersial dan non komersial, dan ketentuan larangan klausula baku untuk proses pra pasar. ${ }^{75}$ Padahal saat ini kelemahan konsumen adalah tingkat kesadaran konsumen akan haknya masih rendah, ${ }^{76}$ terutama karena rendahnya pendidikan konsumen. Untuk masa mendatang, RUU Perlindungan Konsumen menjadi landasan hukum kuat bagi BI dan badan perlindungan konsumen untuk memberdayakan konsumen secara integratif

75 M Dani Pratama Huzaini, "Beberapa Ketentuan Baru Dalam Revisi UU Perlindungan Konsumen”, https://www. hukumonline.com/berita/baca/lt599fdf65cdb86/beberapa-ketentuan-baru-dalam-revisi-uu-perlindungankonsumen/, diakses 30 Agustus 2019.

76 Rizki Tri Anugrah Bhakti dan Padrisan Jamba, "Analisis Yuridis Perlindungan Konsumen Terhadap Informasi Iklan yang Menyesatkan," Jurnal Cahaya Keadilan Vol. 5, No. 1, (2017): 48. 
(tidak terlepas satu sama lain) melalui partisipasi dan sosialisasi masyarakat dalam setiap kebijakan. Hukum yang melindungi konsumen tidak untuk mematikan usaha para pelaku usaha, tetapi melindungi konsumen untuk dapat mendorong iklim berusaha yang sehat dan lahirnya pelaku usaha dan bank yang tangguh dalam menghadapi persaingan melalui penyediaan barang dan/atau jasa berkualitas. Pemberdayaan masyarakat terhadap GNNT melalui partisipasi masyarakat dalam setiap kebijakan BI dan sosialisasi secara berkesinambungan kepada masyarakat dan pelaku usaha untuk mewujudkan keadilan yang berkepastian hukum, yang pada akhirnya manfaat transaksi non-tunai dapat dipetik secara keseluruhan.

Rekomendasi BPKN bahwa GNNT bertujuan untuk meningkatkan kesadaran masyarakat terhadap penggunaan instrumen non-tunai secara berangsur-angsur untuk membentuk masyarakat bertransaksi menggunakan instrumen atas kegiatan ekonominya. Rekomendasi BKPN selaras dengan pemikiran Gustav Radburch terkait penegakan hukum, kebijakan GNNT tidak dapat dilakukan secara terburu-buru bahwa perlu upaya keadilan terlebih dahulu kepada masyarakat, selanjutnya kepastian hukum berupa penegakan kebijakan GNNT dapat dilaksanakan dan memberikan manfaat bagi masyarakat secara keseluruhan.

\section{Kesimpulan}

Berdasarkan uraian di atas dapat disimpulkan beberapa hal sebagai berikut:
(1) Keadilan bagi konsumen yang bertransaksi tunai adalah pelaku usaha (merchant) dan bank yang bekerjasama dengan pelaku usaha menghormati hak konsumen untuk diperlakukan atau dilayani secara benar, jujur, dan tidak diskriminatif oleh pelaku usaha, termasuk cara pembayarannya. Kehadiran uang tunai masih memegang peranan penting dalam kehidupan negara dan rakyatnya. Masyarakat Indonesia belum siap untuk segera melaksanakan GNNT, ketika pemerintah secara tergesa-gesa melaksanakan kebijakan demi mencapai tujuan negara, maka perlunya keadilan dalam menghadapi permasalahan yang muncul yaitu partisipasi masyarakat dalam setiap kebijakan pemerintah (BI) dan sosialisasi kebijakan GNNT, serta penguatan badan-badan perlindungan konsumen untuk menampung aspirasi dan kebutuhan masyarakat (konsumen). Untuk ke depannya, perlu kerja sama pemerintah (BI) dan badan perlindungan konsumen terhadap bank-bank dan lembaga selain bank (perusahaan yang menerbitkan kartu pembayaran) dan pelaku usaha dalam mewujudkan keadilan diantaranya terkait perlakuan merchant terhadap cara pembayaran konsumen.

(2) Promosi dapat dikatakan patut ketika memenuhi asas perlindungan konsumen dalam UU Nomor 8 Tahun 1999 diantaranya manfaat, adil, dan kepastian 
hukum. Ketidakpatutan promosi terjadi ketika konsumen tidak diperlakukan atau dilayani secara benar, jujur, dan diskriminatif termasuk cara pembayaran yang berbeda antar konsumen untuk menarik minat beli oleh merchant dan bank bagi konsumen tunai, maka pentingnya badan-badan yang terus konsentrasi melindungi konsumen secara maksimal (BPSK dan BPKN).

Tujuan kepatutan promosi pada transaksi adalah keadilan bagi setiap konsumen untuk membayar dengan harga yang sama atas barang dan/jasa dan penjual berlaku patut dalam promosinya yang menciptakan penghargaan atas harkat dan martabat seseorang pada transaksi. Kepatutan promosi perlu kerja sama yang baik antara BI dengan badan perlindungan konsumen melalui pengawasan hubungan antara merchant dengan bank untuk dapat merefleksikan keadilan bagi seluruh konsumen termasuk konsumen transaksi tunai di masa mendatang untuk menyongsong era transaksi non-tunai.

\section{DAFTAR PUSTAKA}

\section{Buku}

Ali, H. Zainuddin. Metode Penelitian Hukum. Jakarta: Sinar Grafika, 2014.

Mertokusumo, Sudikno. Mengenal Hukum

Suatu Pengantar. Yogyakarta: Liberty, 1999.

Miru, Ahmadi dan Sutarman Yodo. Hukum Perlindungan Konsumen. Jakarta: PT. RajaGrafindo Persada, 2004.

Muhtar, Gunawan. Kontribusi Organisasi Sosial Dalam Pembangunan Kesejahteraan Sosial. Jakarta: P3KS Press (Anggota IKAPI), 2010.

Nasution, Muhammad Syukri Albani dkk. Hukum Dalam Pendekatan Filsafat. Jakarta: Kencana, 2015.

Nugroho, Susanti Adi. Proses Penyelesaian Sengketa Konsumen Ditinjau Dari Hukum Acara Serta Kendala
Implementasinya. Jakarta: Kencana Prenada Media Group, 2008.

Sekretariat Jenderal Dewan Perwakilan Rakyat. Proses Pembahasan Rancangan Undang-Undang Tentang Perlindungan Konsumen. Jakarta: Sekretariat Jenderal Dewan Perwakilan Rakyat, 2001.

Suseno, Franz Magnis. Etika Politik: Prinsip Moral Dasar Kenegaraan Modern. Jakarta: PT. Gramedia Pustaka Utama, 2016.

Ujan, Andre Ata. Membangun Hukum, Membela Keadilan Filsafat Hukum. Yogyakarta: Kanisius, 2013.

Wibowo, Mardian. Kebijakan Hukum Terbuka Dalam Putusan Mahkamah Konstitusi Konsep dan Kajian Dalam Pembatasan Kebebasan Pembentuk Undang- 
Undang. Depok: PT. RajaGrafindo Persada, 2019.

\section{Jurnal}

Barkatullah, Abdul Halim. "Urgensi Perlindungan Hak-hak Konsumen Dalam Transaksi di E-Commerce," Jurnal Hukum Vol. 14, No. 2, (April 2007).

Bhakti, Rizki Tri Anugrah dan Padrisan Jamba. ”Analisis Yuridis Perlindungan Konsumen Terhadap Informasi Iklan yang Menyesatkan," Jurnal Cahaya Keadilan Vol. 5, No. 1, (2017).

Fadhly, Fabian. "Ganti Rugi Sebagai Perlindungan Hukum Bagi Konsumen Akibat Produk Cacat," Arena Hukum Vol. 6, No. 2, (Agustus 2013).

Hadi, Abdul. "Fenomena Menikah Dengan Teman Sekantor Pasca Putusan Mahkamah Konstitusi Tentang Uji Materi Pasal 153 ayat (1) huruf $\mathrm{f}$ Undang-Undang Nomor 13 Tahun 2003 Tentang Ketenagakerjaan”, Jurnal Surya Kencana Dua: Dinamika Masalah Hukum dan Keadilan Vol. 5, No. 1, (Juli 2018).

Handayani, Tutut. "Membangun Komunikasi Efektif Untuk Meningkatkan Kualitas Dalam Proses belajar mengajar", Ta 'dib Vol. XVI, No. 02, (November 2011).

Harahap, Zairin. 'Pengaturan Tentang

Ketentuan Sanksi Dalam Peraturan Daerah", Jurnal Hukum No. 1, Vol. 13, (Januari 2006).
Holijah. "Pengintegrasian Urgensi dan Eksistensi Tanggung Jawab Mutlak Produk Barang Cacat Tersembunyi Pelaku Usaha Dalam Undang-Undang Perlindungan Konsumen di Era Globalisasi," Jurnal Dinamika Hukum Vol. 14, No. 1, (Januari 2014).

Kirillova, Elena Anatolyevna, etc. "The Principle of the Consumer Right Protection in Electronic Trade: A Comparative Law Analysis", International Journal of Economics and Financial Issues Vol. 6, Special Issue (S2), (2016).

Kristiyanti, Celina Tri Siwi. "Perlindungan Hukum Bagi Konsumen Jasa Keuangan Dalam Perjanjian Baku Dengan Klausula Eksonerasi," Arena Hukum Vol. 12, No. 2, (Agustus 2019).

Llewellyn, Nick. "Money Talks': Communicative and Symbolic Functions of Cash Money," Sage Journals Vol. 50, Issue 4, (2016): 796.

Lukmanulhakim, Muhammad dkk. "Pengaruh Transaksi Non-Tunai Terhadap Velositas Uang Di Indonesia”, Jurnal Ekonomi Pembangunan Vol. 14, No. 1, (Juni 2016).

Mansyur, Ali dan Irsan Rahman. "Penegakan Hukum Perlindungan Konsumen Sebagai Upaya Peningkatan Mutu Produksi Nasional”, Jurnal Pembaharuan Hukum Vol. II, No. 1, (Januari-April 2015). 
Mariana, Dede. "Partisipasi Masyarakat Dalam Proses Kebijakan", CosmoGov Vol. 1, No. 2, (Oktober 2015).

Nelasari, Putri Ratna, dkk. "Pengaruh Sistem Transaksi Non Tunai Terhadap Tingkat Konsumsi Masyarakat Di Surabaya”, Jurnal Ekonomi Islam Vol. 1, No. 2, (2018).

Newsletter Bank Indonesia. "Kreatif Menginisiasi Transaksi Non Tunai”, Ed. 50 Tahun 5 (2014).

Nuryanto, Carto. 'Penegakan Hukum Oleh Hakim Dalam Putusannya Antara Kepastian Hukum dan Keadilan”, Jurnal Hukum Khaira Ummah Vol. 13, No. 1, (Maret 2018).

Petersmann, Ernst-Ulrich. "Theories of Justice, Human Rights, and the Constitution of International Markets", Loyola of Los Angeles Law Review Vol. 37, No. 407, (2003).

Setiantoro, Arfian dkk., "Urgensi

Perlindungan Hukum Konsumen dan Penyelesaian Sengketa E-Commerce Di Era Masyarakat Ekonomi ASEAN", Jurnal Rechtsvinding Vol. 7, No. 1, (April 2018).

Setyawati, Desry Ary dkk. "Perlindungan Bagi Hak Konsumen dan Tanggung Jawab Pelaku Usaha Dalam Perjanjian Transaksi Elektronik," Syiah Kuala Law Journal Vol. 1, No. 3, (Desember 2017).

Sianturi, Mika Hastuti Br. dan Suhadak. "Analisis Pengaruh GNNT (Gerakan
Nasional Non Tunai) Terhadap Nilai Transaksi Nasabah dan Dampaknya Terhadap Makroekonomi Indonesia (Studi pada Bank Indonesia Tahun 2014-2018)", Jurnal Administrasi Bisnis Vol. 70, No. 1, (Mei 2019).

Subiyanto, Achmad Edi. "Perlindungan Hak Konstitusional Melalui Pengaduan Konstitusional," Jurnal Konstitusi Vol. 8, No. 5, (Oktober 2011).

Sulaeman. "Asas Kepatutan Dalam Tanggung Jawab Sosial dan Lingkungan pada Perseroan," Badamai Law Journal Vol. 1, Issues 1, (April 2016).

Sutarmin, dkk. "Potensi Pengembangan Transaksi Non Tunai Di Indonesia", Sustainable Competitive Advantage Journal Vol. 7, No. 1, (2017).

Syamsudin, M. dan Fera Aditias Ramadani. "Perlindungan Hukum Konsumen Atas Penerapan Klausula Baku: Kajian Putusan Nomor 26/P.BPSK/12/2014, Nomor 15/PDT.G/2015/PN.SBY, dan Nomor 184K/PDT.SUS-BPSK/2016," Jurnal Yudisial Vol. 11, No. 1, (April 2018).

Wariati, Ambar dan Nani Irma Susanti. "E-Commerce Dalam Perspektif Perlindungan Konsumen," Jurnal Ekonomi dan Bisnis Vol. 1, No. 2, (November 2014).

Wasiaturrahma, etc. "Non Cash Payment and Demand for Real Money in Indonesia," Journal of Economics, Business, and Accountancy Ventura Vol. 22, No. 1, (April-July 2019). 
Wicaksono, Dian Agung. "Peran Mahkamah Konstitusi Dalam Mewujudkan Fair Equality of Opportunity di Indonesia (Analisis Putusan Nomor 117/ PUU-VII/2009)," Jurnal Konstitusi Vol. 9, No. 1, (Maret 2012).

Winter, Adery P. "Perlindungan Hak-hak Konsumen Terhadap Penggunaan Produk Provider Telekomunikasi Di Indonesia", Jurnal Hukum Unsrta Vol. XXI, Ed. Khusus, No. 4, (April-Juni 2013).

\section{Peraturan Perundang-undangan dan Putusan Pengadilan}

Undang-Undang Nomor 8 Tahun 1999 tentang Perlindungan Konsumen.

Undang-Undang Nomor 7 Tahun 2011 tentang Mata Uang.

Undang-Undang Nomor 12 Tahun 2011 tentang Pembentukan Peraturan Perundang-undangan.

Undang-Undang Nomor 15 Tahun 2019 tentang Perubahan Atas UndangUndang Nomor 12 Tahun 2011 tentang pembentukan Peraturan Perundangundangan.

Putusan Mahkamah Konstitusi Nomor 74/ PUU-IX/2011 perihal Pengujian UU Nomor 8 Tahun 1999 tentang Perlindungan Konsumen.

Putusan Mahkamah Konstitusi Nomor 65/ PUU-XIII/2015 perihal Pengujian UU Nomor 8 Tahun 1999 tentang Perlindungan Konsumen
Putusan Mahkamah Konstitusi Nomor 91/ PUU-XV/2017 perihal Pengujian UU Nomor 8 Tahun 1999 tentang Perlindungan Konsumen.

\section{Naskah Internet}

Arieza, Ulfa. "Perang Diskon dan Masa Depan Uang Elektronik". https://www.cnnindonesia.com/ ekonomi/20190705122825-92-409395/ perang-diskon-dan-masa-depan-uangelektronik. diakses 23 Oktober 2019.

Bank Indonesia. "Bank Indonesia dan Kompasiana: Jelajah Non Tunai”. https://www.bi.go.id/id/ruang-media/ info-terbaru/Pages/Bank-Indonesiadan-Kompasiana-Jelajah-Non-Tunai. aspx. diakses 26 Agustus 2019.

Catriana, Elsa. "Studi: Transaksi Nontunai di Indonesia Capai 128 Triliun pada 2019”. https://money.kompas.com/ $\mathrm{read} / 2020 / 01 / 15 / 130200026 /$ studi-transaksi-nontunai-di-indonesia-capairp-128-triliun-pada-2019? page $=$ all . diakses 28 November 2020.

CNN Indonesia. "Sempat Pelopori Uang Elektronil, Kini Jepang Jauh Tertinggal". https://www.cnnindonesia. com/ekonomi/2019082115235978-423418/sempat-pelopori-uangelektronik-kini-jepang-jauh-tertinggal. diakses 23 Oktober 2019.

"Waspada Bahaya mengintai di Era Cashless Society". https://www.cnnindonesia.com/ 
ekonomi/20190308142700-83-375574/

waspada-bahaya-mengintai-di-eracashless-society. diakses 18 Oktober 2019.

Deny, Septian. "5 Negara Paling Banyak Bertransaksi Tunai”. https:// www. 1 iputan 6 . com/bisnis / read/2138000/5-negara-palingbanyak-bertransaksi-non-tunai?utm_ exp id $=.9$ Z 4 i 5 y p G Q e G i S 7 w 9 a $\mathrm{r}$ w $\mathrm{T}$ v Q . 0 \& $\mathrm{u} \mathrm{t} \mathrm{m}$ referrer $=$ https $\% 3 \mathrm{~A} \% 2 \mathrm{~F} \% 2 \mathrm{Fwww}$. google.com $\% 2 \mathrm{~F}$. diakses 30 Agustus 2019.

Huzaini, M Dani Pratama. "Beberapa Ketentuan Baru Dalam Revisi UU Perlindungan Konsumen". https:// www.hukumonline.com/berita/baca/ 1t599fdf65cdb86/beberapa-ketentuanbaru-dalam-revisi-uu-perlindungankonsumen/. diakses 30 Agustus 2019.

"Menelaah

Dampak kebijakan Transaksi Non Tunai”. https://www.hukumonline. com/berita/baca/ 1t59eeee27121aa/ menelaah-dampak-kebijakantransaksi-non-tunai/. diakses 18 Oktober 2019.

Kompas.com."7ManfaatMengelolaKeuangan Dengan Baik". https://money.kompas. com/ $\mathrm{read} / 2016 / 11 / 15 / 052648726 / 7$. manfaat. mengelola.keuangan.dengan. baik?page $=$ all. diakses 28 Oktober 2019.

Kompasiana. "Edukasi Transaksi Non
Tunai”. https://www.kompasiana. com/a idaram li/ 555805 a 8 b 67e61925b66c09e/edukasi-transaksinon-tunai. diakses 21 Oktober 2019.

--------------. 'Peluang, Tantangan, dan Upaya Mendorong Gerakan Nasional Non Tunai (GNNT) Di Indonesia". https://www.kompasiana.com/ oesmarini/557d1a738efdfdeb6ff37aa6/ peluang-tantangan-dan-upaya-dalammendorong-gerakan-nasional-nontunai-gnnt-di-indonesia? page $=$ all . diakses 21 Oktober 2019.

"Sosialisasi Gerakan

Nasional (GNNT) Pentingkah?”. https://www.kompasiana. com/ ttaqin98/5bf532acab12ae5d6a2ed685/ sosialisasi-gerakan-nasional-non-tunaignnt-pentingkah?page $=$ all. diakses 23 Oktober 2019.

Rahma,Athika. "Kasus Monopoli OVO Masuk Penyelidikan KPPU". https://www. liputan6. com/bisnis/read/4047520/ kas u s-monopoli-ovo-mas ukpenyelidikan-kppu?utm_expid=.9Z4i5 ypGQeGiS7w9arwTvQ.0\&utm referrer $=$ https $\% 3 \mathrm{~A} \% 2 \mathrm{~F} \% 2 \mathrm{Fwww}$. google.com\%2F. diakses 27 Agustus 2019.

Rezkisari, Indira. "Gerakan Non-Tunai hemat Rp 16 T Biaya Cetak Uang”, https://www.republika.co.id/berita/ dunia-islam/fatwa/14/07/21/ekonomi/ keuangan/17/10/18/oy0k63328gerakan-nontunai-hemat-rp-16-t-biayacetak-uang. diakses 26 Agustus 2019. 
Rosyadi, Dede. "Menjaga Rupiah Sebagai Yusra, Yenny. "Potensi Perluasan "Cashless Simbol Kedaulatan NKRI". https:// www.merdeka.com/uang/menjagarupiah-sebagai-simbol-kedaulatannkri.html. diakses 28 Oktober 2019.
Society" di Indonesia". https:// dailysocial.id/post/potensi-perluasancashless-society-di-indonesia. diakses 28 November 2020. 